\title{
The Upper Silurian of Touat (Algerian Sahara) and its fauna
}

\author{
PHILIPPE LEGRAND
}

\begin{abstract}
In the Touat region (Algerian Sahara), the most complete Palaeozoic succession occurs to the southwest of Adrar. In the Tamest section, the Silurian comprises the Fenourine Clay and the Touat Sandstone formations. The Fenourine Clay Formation consists mostly of silty claystones of which only the upper $150 \mathrm{~m}$ crop out. At the base of the section, bivalves occur, followed by the graptolites Saetograptus chimaera aff. salweyi (Hopkinson) and Pristiograptus cf. P. tumescens minor (Wood) which are described and figured in this paper. The overlying Touat Sandstone Formation is $170 \mathrm{~m}$ thick. It comprises silty claystones with several lenticular, sandy beds, surmounted by a sandy, calcareous bed. At the base of the sandstone, pieces of homalonotine trilobites, brachiopods and bivalves are present. Above the base, silty claystones, a ferrugineous siltstone bed and the first Tentaculoidea occur. A conglomeratic limestone bed yielding a Pragian fauna tops the formation. The ages are as follows: the lower and middle Silurian do not crop out. The graptolites at the base of the extant section belong to the associations $\sigma 3 \beta$ which characterize the Saharan Ludlow Series (g3b) (Legrand 1981, 1985). The silty, clayey beds that follow may be the equivalent of the Př́dolí (g3c). The fossiliferous beds at the base of the Touat Sandstone may also be of Př́dolí age, or may indicate the base of the Lochkovian $(\mathrm{g} 4 \mathrm{c})$. These outcrops reveal an interesting evolution in terms of facies and faunal assemblages towards the Ougarta Mountains and the Gourara to the northwest and the Azzel Matti to the southeast. Key words: Algerian Sahara, Touat, Silurian, graptolites, bivalves.
\end{abstract}

LEgRAND, P. 2012. The Upper Silurian of Touat (Algerian Sahara) and its fauna. Bulletin of Geosciences 87(4), 661-668 (4 figures). Czech Geological Survey, Prague. ISSN 1214-1119. Manuscript received July 29, 2011; accepted in revised form March 29, 2012; published online May 15, 2012; issued October 17, 2012.

Philippe Legrand, Tauzia, 216 cours Général de Gaulle, 33170 Gradignan, France; legandblain@wanadoo.fr

In the Touat region of the Algerian Sahara, the most complete Palaeozoic succession is located to the southwest of Adrar (Fig. 1). However, strata of "Continental Intercalaire" (Cretaceous), Mio-Pliocene and Quaternary age overlie the lower and middle Silurian and part of the Famennian. The beds dip regularly to the southwest, and belong to the eastern limb of a broad asymmetrical syncline, the other limb of which crops out in the eastern extremity of the Eglabs.

The significance of these outcrops lies in the fact that they are situated halfway between the southern end of the Ougarta Mountains (Djebel Hèche Section, Gourara) and the northernmost outcrops of Azzel Matti (Aïn ech Cheikr Section) (Fig. 1).

From a structural viewpoint (Legrand 1985), the Palaeozoic outcrops are to the south of the intersection of two major Saharan platform trends: the W-E trend of the northern border of the Eglabs, which is probably the oldest (Early Proterozoic); the NW-SE trend of the Ougarta Mountains of pan-African age (Late Proterozoic). However, the present outcrops show yet the trend NW-SE and not the N-S trend shown by the Reggane belt, also of pan-African age, which is often considered as following on the previous one.

\section{Historical background}

The Palaeozoic outcrops of Touat were first reported by Gautier (1908), but Meyendorff (1939) deserves the credit for clearly indicating the occurrence of Silurian strata, although without recording any palaeontological evidence. Meyendorff attributed to the Silurian the "argillaceous and sandy shales interbedded with limestones with fragments of Cardioles and Orthoceras". According to him, the Lower Devonian began with the sandy shales with pieces of the trilobite Homalonotus and rhynchonellid brachiopods. Probably, these are the same beds the brachiopod fauna of which is mentioned below.

The beginning of oil exploration next saw the Palaeozoic outcrops studied [by, among others, Compagnie Française des Pétroles (Algérie), 1953 and Bureau des Recherches Pétrolières, 1954]. A section was compiled by Burollet \& Manderscheid and later published by Legrand (1962). A doubtful specimen of "Monograptus" colonus found in a broken sample again suggested the presence of the lower Ludlow. From the beds with small brachiopods, Camarotoechia nucula (Sowerby) and C. eg. tarda (Barrande) (identifications by D. le Maître) were listed. In 1968, 


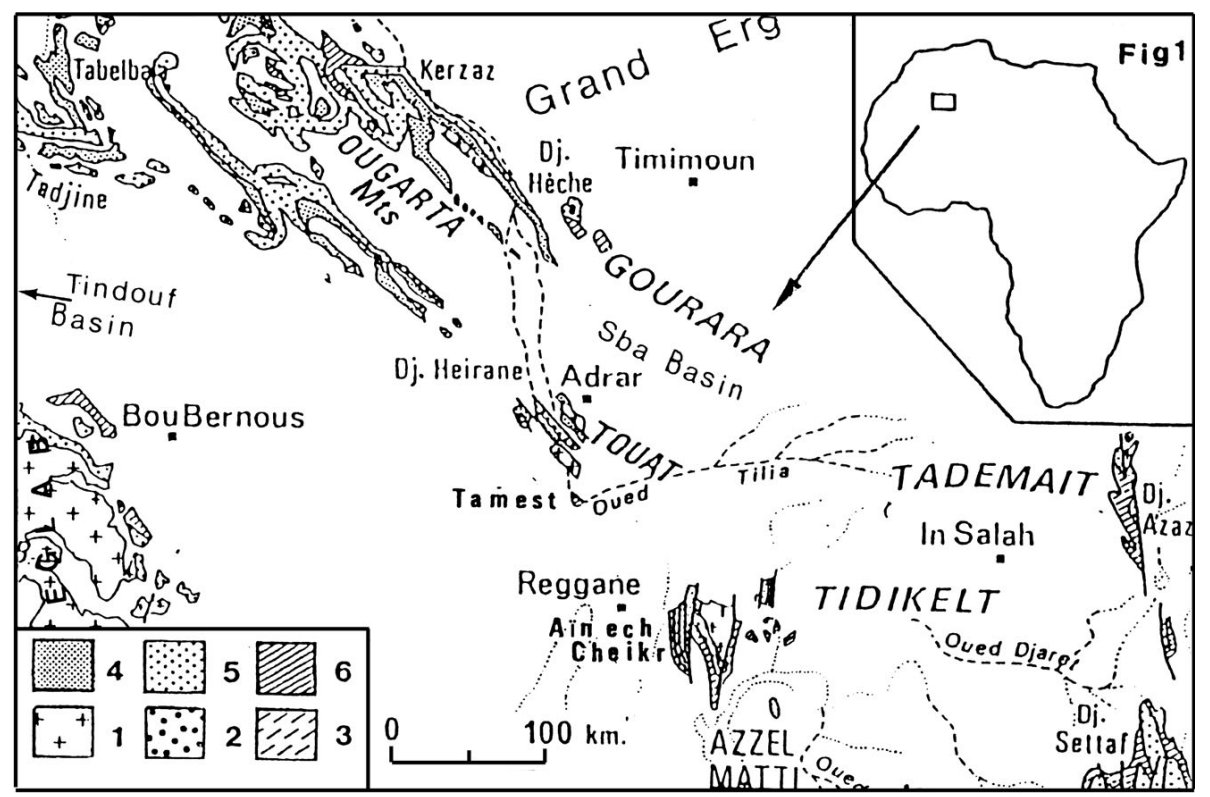

Figure 1. Location map of the study area. Lower Palaeozoic outcrops: 1 - Precambrian; 2 - lower Cambrian; 3 - uppermost Cambrian; 4 - Cambrian of Ougarta Mountains, Gourara, Touat, and Bled el Mass; 5 - Ordovician; 6 - Silurian (map from Legrand 1999).

these outcrops were re-examined by the author and later briefly described (Legrand 1985). An early Ludlow age for the first calcareous bed was confirmed and a Př́dolí age proposed for the beds containing brachiopods (Legrand 1985).

\section{Section description}

The studied section (Figs 2, 3) is known as either the Tamest section, or Section at $10 \mathrm{~km}$ southwest of El Ahmar. The following lithostratigraphical units have been recognised:

The Fenourine Clay Formation (Legrand 1962, 1967, 1985). Only its upper part (about $150 \mathrm{~m}$ and not $200 \mathrm{~m}$ as previously measured) is visible, and this consists mainly of argillaceous siltstones with some interbedded calcareous sandstones, sandy limestones and fine-grained sandstone. The lower claystones have yielded the bivalves (identifications by C. Babin) Butovicella sp. and Mytilarca $\mathrm{cf}$. M. esuriens (Barrande), while the lowest sandy-calcareous bed has yielded the graptolites Saetograptus chimaera aff. S. salweyi (Hopkinson) and Pristiograptus cf. P. tumescens minor (Wood), as well as the bivalve Dualina sp. and many scolecodonts. Further up in the section, besides many shells of "Orthoceras", a bed with the brachiopod Hypselonetes? sp. (identification by P.R. Racheboeuf) and pieces of homalonotine trilobites has been noted. All excavations in the upper part of the formation have revealed barren, silty clay.

The Touat Sandstone Formation (Legrand 1962, 1967, 1985). This is a thick $(170 \mathrm{~m})$ unit of silty claystones with interbedded sandstones and a prominent sandstone at the top. At the base are beds of beige- or greenish, fine to microconglomeratic sandstones with intercalated fossiliferous, amygdaloidal sandy limestone beds separated by silty claystones. Numerous bivalves were collected here: Cypricardella sp., Phestia sp., Modiomorpha sp., Paleoneilo? sp., Nuculites sp., Grammysoidea sp., Myophoria sp., Leptodesma sp. (identifications by C. Babin), as well as ostracods, gastropods, "Orthoceras" and rare Homalonotinae. Brachiopods are also abundant, but they have not been studied.

Above the silty claystones, partly covered by overburden, is the main argillo-ferruginous unit of siltstones with the first Tentaculoidea. Above the silty sandstones, beginning with a bed of ferruginous sandstone, the strata become progressively sandier terminating as irregularly stratified, fine- to medium-grained sandstones with sparse fossiliferous calcareous intercalations.

\section{Biostratigraphical dating}

As graptolites are rare in the Algerian Sahara, graptolite associations combining several graptolite biozones have been defined. In a similar way, regional stages and substages were defined later (Legrand 1981, 1985).

Graptolites from the lower sandy limestone of the Fenourine Clay Formation belong to the group of associations $\sigma 3 \beta$ that characterizes the Ludlow of the Algerian Sahara. More precisely, they could belong to the association $\sigma 3 \beta 3$ or $\sigma 3 \beta 2$ that characterize the regional substages g $3 b 3$ or $\mathrm{g} 3 \mathrm{~b} 2$, which are equivalent to the upper or middle part of the lower Ludlow.

The very fossiliferous beds at the base of the Touat Sandstone Formation are postulated to be of Přídolí age (g3c). Above them, it is possible that the first level of ferruginous siltstone with Tentaculoidea is of Devonian, more precisely Lochkovian (g4) age, in a Gedinian facies. 


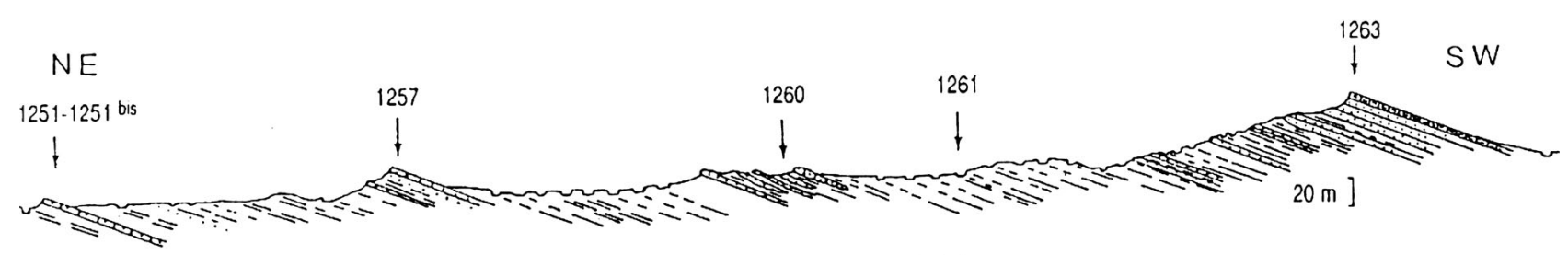

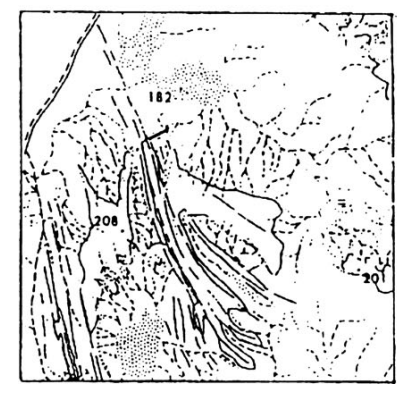

Earlier fossil lists (Legrand 1968) indicated a Pragian age for the upper part of the Touat Sandstone Formation.

\section{Sedimentology and palaeoecology}

Dark claystones occur only at the base of the section. They are interpreted as having been laid down in a dysoxic rather than an anoxic environment, according to the seasonal model of Tyson \& Pearson (1991), which best fits the great epicontinental Palaeozoic sea (Legrand 1999). The occurrence of bivalves (listed above) does not necessarily contradict this. Rather than to see in them a benthic fauna, they may have belonged to the epiplankton attached to algae as pseudoplankton (Seilacher et al. 1968), as has been suggested for small brachiopods (Ruedemann 1934, Havlíček 1967, Spjeldnaes 1967).

The graptolites are of small size, limited to two taxa, and are confined to a single sandy calcareous bed. They indicate an unfavourable local environment with restricted communications.

Above the basal claystones, all claystones are light grey in colour, as also observed in the Př́dolí strata of the Ougarta Mountains. The siltstones become siltier and more numerous higher in the section. The environment is interpreted to have remained dysoxic, although richer in oxygen, if the Strophochonetidae-Homalonotinae association, so common in the Algerian Sahara, is regarded as benthic and indicative of shallow water.

Better oxygenation and increasing detrital input are evident at the base of the Touat Sandstone Formation. The accumulation of bivalves from different environments and with different life habits (endobenthic, semi-endobenthic, epibenthic), together with borings into the largest shells indicate reworking within a thanatocoenosis. The taxonomic diversity and the large size of some shells suggest both a better oxygenated environment and a more abundant food supply. The origin of the sediment remains uncertain; the most probable source is from the south because clastic sedimentation had begun in the Western Tassilis at the end of the Wenlock, although the borders with the Eglabs cannot be ignored as another potential source.

A decrease in water depth stratigraphically upwards is also suggested by the increase in abundance of trace fossils. However, the environment remained marine and the shelly beds show complete faunal changeovers at several stratigraphical levels.

\section{Comparison with the surrounding regions}

To the northwest. - The Ougarta Mountains. The upper Silurian of Touat appears to differ from that of the Ougarta Mountains, although it is contiguous with it. In the Draa Oued Ali section, the Př́idolí extends through most of the middle member of the Oued Ali Clays Formation (except for the calcareous beds and the basal claystones of Ludlow age) and the lower part of the upper member (Legrand 1985). It consists of light grey claystones, approximately $250 \mathrm{~m}$ thick, with rare carbonate beds, but without notable silty interbeds, in which graptolites, although present, are rare, bivalves are common, and several levels of scyphonocrinids occur.

Gourara. In the Djebel Hèche section, the Přídolí is represented by much of the $c a 250 \mathrm{~m}$ thick upper member of the Fegaguira Clay (Legrand 1985). It is mainly argillaceous, but graptolites are absent and bivalves rare.

In conclusion, the upper Silurian of Touat seems to be more condensed, but siltier than the time equivalent deposits to the north. It lacks graptolites and scyphocrinids, but it is rich in brachiopods and large bivalves. Structural elements such as the Sba Basin lie between these two regions, and may have played a rôle prior to the deposition of Př́idolí. 
To the southeast. - Azzel Matti. The upper Silurian of this region has not been studied extensively from a biostratigraphical viewpoint. In the more northerly section, known as the Aïn ech Cheik section, the Prrídolí is represented mainly by the upper member of the Aïn ech Cheikr Clay Formation (except for the carbonate sequence at the base of the Ludlow), about 240 m thick. The SilurianDevonian boundary may be located in the upper part of this argillaceous formation or in the lower part of the overlying Sebkha Mekerrhane Sandstone Formation (= Aïn ech Cheikr Sandstone Formation, a name previously used for an Ordovician formation; Legrand 1985). It is a thick, argillaceous unit with numerous, intercalated silty and sandy layers, somewhat similar to the Touat Formation, but essentially barren of fossils.

\section{Systematic palaeontology}

All graptolites come from a calcareous, sandy bed (see Fig. 3), in which they are usually preserved as more or less flattened internal moulds. Traces of periderm are rare. The most delicate parts, such as the apertural spines, are locally preserved, but it is difficult to assess the extent of preservation of the apertural lappets.

The specimens described herein are stored at University Lyon 1, Laboratoire Paléoenvironnement et Paléobiosphère, Pôle Collections.

Order Graptoloidea Lapworth, 1875

Suborder Monograptina Lapworth, 1880

Family Monograptidae Lapworth, 1873

\section{Genus Pristiograptus Jaekel, 1889}

\section{Pristiograptus cf. tumescens minor (Wood, 1900)} Figure 4A-D

cf. 1855 Graptolites ludensis var. minor (McCoy); M'Coy, p. 5 (nomen nudum).

cf. 1900 Monograptus tumescens var. minor (M'Coy). Wood, p. 459, pl. 25, figs 6A, B.

cf. 1910 Monograptus tumescens var. minor (McCoy). - Elles \& Wood, p. 381, text-fig. 250, pl. 37, figs 13a-c.

cf. 1943 Monograptus tumescens var. minor (McCoy). Přibyl, p. 18, text-fig. 1, figs ?4, ?5; text-fig. 2, fig. $\mathrm{CH}$.

cf. 1948 Pristiograptus (Pristiograptus) tumescens minor (McCoy). - Přibyl, p. 77.

cf. 1952 Pristiograptus (Pristiograptus) tumescens cf. minor (M'Coy). - Münch, p. 87, pl. 18, fig. 13.

cf. 1967 Pristiograptus tumescens minor (Wood). - Ulst in Gailite et al., p. 249, fig. 64, pl. 28, figs 12, 13. cf. 1997 Pristiograptus tumescens minor (M'Coy). - Strachan, p. 114.

Material. - A dozen internal moulds in semi-relief: 1251 to a1-12, b1. Upper Member of the Fenourine Clays Formation, Tamest section (Touat region); association $\sigma 3 \beta 3$; biozone uncertain, lower Ludlow.

Description. - Rhabdosomes usually of small size, from about $10 \mathrm{~mm}$ to as much as 12 or $15 \mathrm{~mm}$ long. The dorsal margin is often ventrally curved from the proximal end up to the level of th5 or th6, even of th7. The angle of divergence from the axis of rhabdosome is about $10^{\circ}$. The sicula follows this curvature. Further dorsal wall is straight or, more rarely, gently curved, with the sicula forming a slight hump. The rhabdosome widens gradually from $0.8-0.9 \mathrm{~mm}$ across the aperture of th1 $(0.7-1 \mathrm{~mm})$ to $1.5-1.6 \mathrm{~mm}$ at the level of th4 (sometimes a little less: $1.3-1.4 \mathrm{~mm}$ ) and reaches a maximum of 1.6-1.8 $\mathrm{mm}$ (exceptionally $2.2 \mathrm{~mm}$ ) distally. The sicula is $1.8-2.1 \mathrm{~mm}$ long, its apex often attaining a level between the apertures of th 3 and th4. The sicular aperture is $0.2-0.4 \mathrm{~mm}$ wide and lacks an apertural tongue, but possesses a tiny virgella. Th1, the ventral prothecal wall of which is more or less concave, is 1.0-1.2 mm long; its aperture is clearly everted and its border has been thickened in one specimen (Fig. 3D). The remainder of the thecae are tubes normally $2 \mathrm{~mm}$ long $(1.8-2.2 \mathrm{~mm})$ and $0.4 \mathrm{~mm}$ wide, with a thecal overlap ranging from $2 / 3$ to $3 / 5$. Thecae are inclined $30-35^{\circ}$ to the axis of the rhabdosome. Their apertures seem to be moderately everted, but the apertural border in flattened rhabdosomes appears to be thick and very slightly wavy. There are 13-14 thecae in $10 \mathrm{~mm}$.

Discussion. - The specimens resemble Colonograptus colonus colonus (Barrande) because of their appearance and the proximal ventral curvature. The size is smaller than usual for this species in which the width attains a maximum of $2.0-2.3 \mathrm{~mm}$. The number of thecae in $10 \mathrm{~mm}$ is also similar. On the other hand, the sicula is longer ( $2 \mathrm{~mm}$ instead of $1.6 \mathrm{~mm}$ ) and the initial thecae seem to be tubular with a simple aperture. However, in some specimens th1 shows a concavo-convex ventral wall, which in flattened specimens may indicate the outline of apertural lappets, as in praedeubeli which is of uncertain generic affiliation. However, this is not what one observes in Colonograptus colonus colonus, including the original material (Přibyl 1942, Urbanek 1958) and in figures that differ from it (see Jaeger 1978, figs 6-8). One might suppose that the apertural lappets have been mechanically destroyed, but, as the destruction would have to have affected all specimens, this seems unlikely.

These specimens also resemble the type specimens of Pristiograptus tumescens minor (Wood) in both their general form and the ventral curvature of the proximal part. However, the identity of P. t. minor is problematical. 


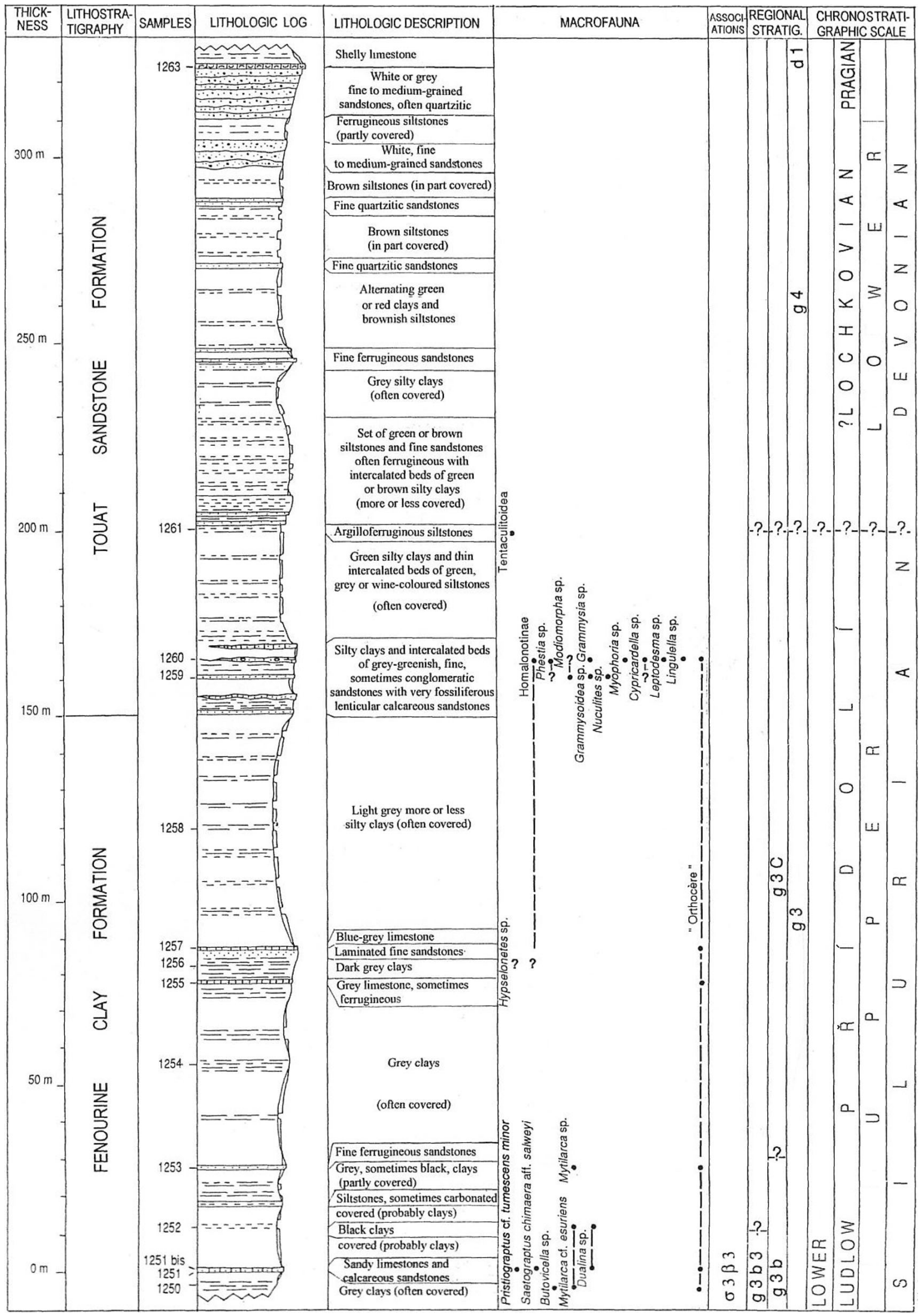

Figure 3. Lithological and stratigraphical logs of the Tamest section (upper Silurian- lowermost Devonian; Legrand, January 1968, unpublished). 
The subspecies Graptolites ludensis minor was described by McCoy (1855), but not figured. Wood (1900), believing that she had found McCoy's originals, attributed the subspecies to McCoy, but related it to the species tumescens with which it is associated. Two specimens were figured (Wood 1900, pl. 25, figs 6A, B). Elles \& Wood (1910, pl. 37, figs 13a-c) adopted Wood's viewpoint and figured three specimens and the proximal end of one of them (text-fig. 250), but did not define the morphology of the taxon besides a maximum length of $13 \mathrm{~mm}$. Přibyl (1942), wrongly in my opinion, attributed the taxon to McCoy and chose as lectotype the specimen figured by Wood (1922, pl. 25, fig. 6A). Strachan (1997) adopted the same view and identified the lectotype as specimen BU 1475 (housed in the Lapworth Museum, University of Birmingham). For Elles \& Wood (1911) the subspecies minor differs from species tumescens only in its smaller size. However, this subspecies has never been fully described, although the lectotype of tumescens has been refigured with additional information by Zalasiewicz (in Zalasiewicz et al. 2000). According to Elles \& Wood, the maximum breadth is $2.0 \mathrm{~mm}$ and "the thecae show a somewhat thickened apertural margin, which after compression gives rise to a distinct denticle". The number of thecae in $10 \mathrm{~mm}$ is typically $9-10$, but is $12-13$ in the more robust forms. The sicula would be less than $2 \mathrm{~mm}$ long.

In conclusion, although the status of $P$. tumescens minor remains insecure, the identity with the Touat specimens is considered most likely on present evidence.

Stratigraphical range. - In the British Isles Pristiograptus tumescens minor is associated with the biozonal index species Pristiograptus tumescens, collected from near the top of the lower Ludlow (Gorstian) by Rickards (1989). In Bohemia, this species characterizes the transition between the scanicus Biozone and the fritschi linearis Biozone. This is the first time that this species has been recorded from the Algerian Sahara. If it has the same range, it could belong to the association $\sigma 3 \beta 3$ characterizing substage g3b3 (the upper part of the lower Ludlow), but this remains to be confirmed. It should be noted that by bringing these specimens closer to Colonograptus, an older age (substage g3b2) (the middle part of the lower Ludlow) would be suggested.

\section{Saetograptus chimaera aff. salweyi (Lapworth, 1880)} Figure 4E, F

aff. 1873 Monograptus salweyi sp. nov.; J. Hopkinson, p. 520 (nomen nudum).

aff. 1880 Monograptus Salweyi Hopk. - Lapworth, pp. 150, 151, pl. 4, figs 2a, 2b. aff. 1884 Monograptus chimaera (Barrande). - La Touche, p. 77 , tab. 18, fig. 571.

aff. 1900 Monograptus chimaera var. salweyi Wood. - Wood, p. 472 , text-fig. 18 , pl. 18, figs 19A, B.

aff. 1910 Monograptus chimaera Barr. var. Salweyi (Hopkinson MS). - Elles \& Wood, p. 400, text-fig. 267a, b, pl. 34, fig. 5a-d.

aff. 1935 Monograptus chimaera Barr. var. Salweyi (Hopk.). Ianishevsky, pp. 25, 26, pl. 3, figs 8, 9a, b.

aff. 1938 Monograptus cf. uncinatus var. orbatus Wood. Münch, pp. 60, 61, pl. 5.

aff. 1942 Pristiograptus (Saetograptus) chimaera Salweyi (Lapworth, 1880, Hopkinson MS). - Přibyl, pp. 14-16, text-fig. 3, figs 1, 2.

aff. 1945 Monograptus chimaera var. Salweyi Hopk. - Waterlot, p. 74, tab. 29, fig. 308.

aff. 1948 Pristiograptus (Saetograptus) Salweyi (Lapworth). Přibyl, p. 81.

aff. 1952 Saetograptus chimaera salweyi Lpw.-Hopk. MS. Münch, p. 97, pl. 24, fig. 3a, b.

aff. 1956 Pristiograptus (Saetograptus) chimaera salweyi (Lapworth). - Tomczyk, pp. 56, 57, 91, 92, 117, figs 16c, d, tab. 8, fig. 1.

aff. ?1958 Saetograptus chimaera salweyi (Hopkinson).--Urbanek, pp. 56, 57, pl. 2, fig. 3a, b.

aff. ?1958 Saetograptus chimaera var. salweyi (Lapworth). Spasov, p. 63, pl. 9, fig. 6 .

aff. 1965 Saetograptus chimaera salweyi (Lapworth). - Obut \& Sobolevskaya, p. 74, pl. 13, fig. 6.

aff. 1997 Saetograptus (Saetograptus) chimaera salweyi (Lapworth). - Strachan, p. 118.

Material. - Seven flattened specimens: 1251 bis d1-7. Upper Member of the Fenourine Clays Formation, Tamest section (Touat region); association $\sigma 3 \beta 3$; biozone uncertain, lower Ludlow.

Description. - Rhabdosome small, barely exceeding $10 \mathrm{~mm}$ long. The dorsal wall of the rhabdosome is straight, with a slight, concavo-convex curvature at the level of the sicula. The width of the rhabdosome is $0.7 \mathrm{~mm}$ across the aperture of th1 (spine not included). At first it widens slowly: $0.8 \mathrm{~mm}$ at th2, $1 \mathrm{~mm}$ at th4, to $1.6 \mathrm{~mm}$ distally. However, in one specimen, the breadth remains $1 \mathrm{~mm}$ throughout the length of the rhabdosome. The sicula is at least $1.6 \mathrm{~mm}$ long, with the apex between the level of the apertures of th 3 and th 4 , although this is difficult to define accurately. It is $0.2 \mathrm{~mm}$ wide aperturally. The virgella is short ( $0.2 \mathrm{~mm}$ long). Thecae are simple tubes with th1 showing a slightly concave ventral wall. Th1 is $1 \mathrm{~mm}$ long and mature thecae are between 1.6 and $1.8 \mathrm{~mm}$ long and $0.4 \mathrm{~mm}$ wide; the amount of overlap is $3 / 4$ and the angle of inclination $35^{\circ}$. At the level of their apertures, the thecae possess two lateral spines, $0.3-0.4 \mathrm{~mm}$ long, rising from each 
side of the lateral border of the aperture; they curve more or less towards the sicula. There are 8 thecae in the first $5 \mathrm{~mm}$ and $14-15$ in the following $10 \mathrm{~mm}$ of the rhabdosome.

Discussion. - These specimens clearly belong to the Saetograptus chimaera group with which they share the thecal style and the characteristic lateral thecal spines. However, they do not seem to fit any known taxon. They are similar to $S$. chimaera salweyi (Lapworth) in their small size, nearly straight aspect and slight width. They differ from it by the shorter spines and high number of thecae in $10 \mathrm{~mm}$. This is possibly a local subspecies that cannot be assigned to any known taxon because of the poor quality of the material available. In some characters such as the number of thecae in $10 \mathrm{~mm}$, the specimens are similar to Saetograptus? leintwardinensis (Hopkinson). However, the form of the sicula and the position of the spines rule out such link. Indeed, Wood (1900) categorically, and Elles \& Wood (1911) more cautiously describe the origin of the spines in S.? leintwardinensis as dorsal and not lateral, an opinion shared by R.B. Rickards (written communication, February-March 2004), although Maletz (1997) has disputed this distinction.

Stratigraphical range. - The available data on the range of $S$. chimaera salweyi are divergent. According to Rickards (1976), the subspecies occurs in the upper part of the nilssoni Biozone and the scanicus Biozone of the British Isles. However, Lawson \& White (1989) recorded S. chimaera salweyi only in the tumescens Biozone. In Bohemia, Přibyl (1942, 1948) reported this subspecies from the nilssoni Biozone and the scanicus Biozone, whereas in Poland Teller (1969) attributed to it a shorter range in the boundary interval of the invertus and hemiaversus subbiozones, equivalent to the upper part of the tumescens Biozone. As the Saharan specimens are presently known only from one locality in association with another taxon of uncertain age and belonging to the association $\sigma 3 \beta$ and more probably $\sigma 3 \beta 3$, an early Ludlow age only can be inferred.

\section{The Silurian fauna of Touat in the north Gondwanan context}

The Ludlow graptolites of the Touat region show a noteworthy local specificity as they are pelagic species, whereas the occurrence of numerous species from Bohemia in the Algerian Sahara (Legrand 1981) in silled basins poses a problem of circulation. On the other hand, the other Silurian faunas of the Touat area, such as the bivalves, are typically Gondwanan with obvious affinities with the faunas of Bohemia, the Montagne Noire and Sardinia. This also applies to the bivalves from the western Algerian Sahara.

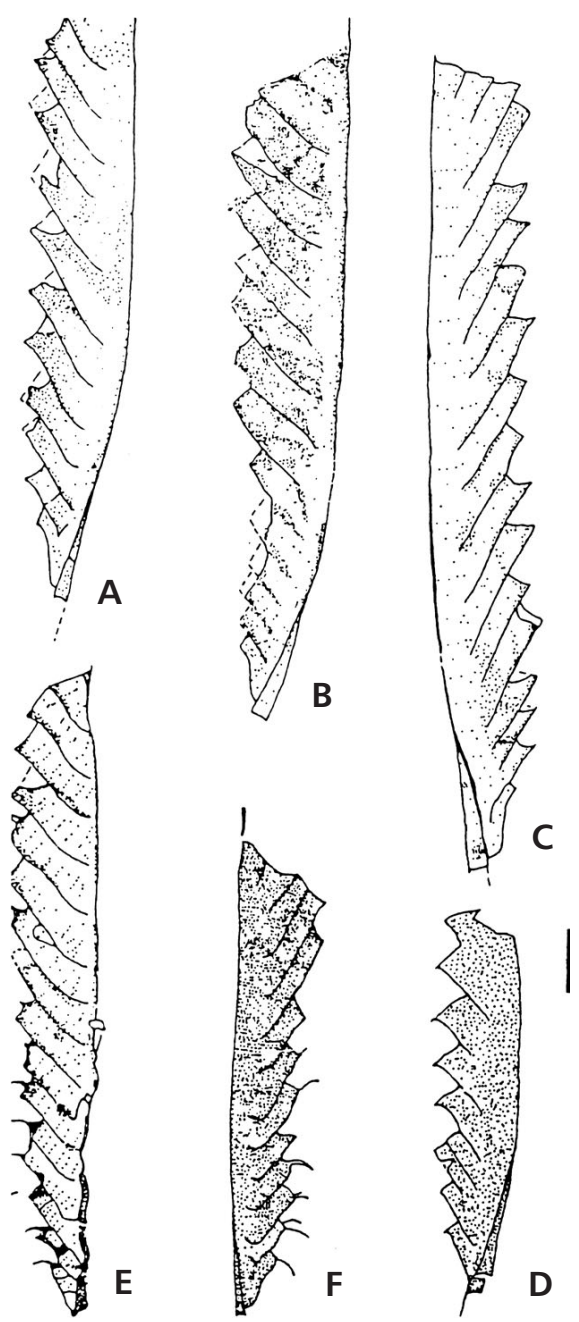

Figure 4. Graptolites of the Tamest section. - A-D - Pristiograptus cf. tumescens minor (Wood). • A - specimen 1251bis a1; B - specimen 1251 bis a6; $\mathrm{C}$ - specimen 1251 bis a7; D - specimen 1251 bis a8. • E, F Saetograptus chimaera aff. salweyi (Lapworth). E - specimen 1251 bis d1; $\mathrm{F}$ - specimen 1251 bis $\mathrm{d} 2$. Scale bar represents $1 \mathrm{~mm}$ for all specimens.

\section{Acknowledgements}

The author is grateful to C. Babin for identifying the bivalves notwithstanding their poor state of preservation and commenting on their palaeoecological significance, and to P.R. Racheboeuf, who kindly studied the specimens from the Strophochonetidae bed. He thanks also J. Riva who corrected the first English text, and the reviewers J. Zalasiewicz and P. Storch for critically reading the manuscript and valuable suggestions.

\section{References}

ELLES, G.L. 1944. The identification of graptolites. Geological Magazine 81, 145-158. DOI 10.1017/S0016756800075245

ElLes, G.L. \& WoOD, E.M.R. 1911. A monograph of British graptolites. Part VIII. Palaeontographical Society, Monograph 1910, 359-414. 
Gautier, E.F. 1908. Sahara algérien. 362 pp. Armand Colin, Paris.

Gaylite, L.K., Rybnikova, M.V. \& Ulst, R.J. 1967. Stratigrafiya fauna i usloviya obrazovaniya siluriyskikh porod sredney pribaltiki. 304 pp. Izdatel'stvo "Zinatue", Riga.

Havlíčex, V. 1967. Brachiopoda of the Suborder Strophomenidina in Czechoslovakia. Rozpravy Ústředního ústavu geologického 33, 1-235.

Hopkinson, J. 1873. On the occurrence of numerous species of graptolites in the Ludlow Rocks of Shropshire. Geological Magazine 10, 519-520.

IANISHEvSKY, M. 1935. Graptolity Novoy Zemli. Trudy Arkticheskogo Instituta 25, 1-55.

JAEGER, H. 1978. Entwicklungszüge (Trends) in der Evolution der Graptolithen. Schriftenreihe für geologische Wissenschaften $10,5-58$.

JAEKEL, O. 1889. Über das Alter des sogen. Graptolithengesteins mit besonderer Berücksichtigung der in demselben enhaltenen Graptolithen. Zeitschrift der Deutschen Geologischen Gesellschaft 41, 653-716.

LaPWORTh, C. 1880. On new British Graptolites. Annales and Magazine of Natural History 5(5), 149-177.

La Touche, J.D. 1884. A handbook of the geology of Shropshire. 91 pp. E. Stanford, London.

Lawson, J.D. \& White, D.E. 1989. The Ludlow Series in the Ludlow area, 73-90. In Holland, C.H. \& Bassett, M.G. (eds) A global standard for the Silurian System. National Museum of Wales, Geological series 9.325 pp. Cardiff.

Legrand, P. 1962. Connaissances acquises sur la limite des systèmes Silurien et Dévonien au Sahara septentrional, 151-159. In ErBen, H.K. (ed.) Symposium-Band Silur/DevonGrenze, Bonn-Bruxelles, 1960. Stuttgart.

Legrand, P. 1968. Le Dévonien du Sahara algérien, 254-284. In OswaLd, D.H. (ed.) International Symposium on the Devonian System, Calgary 1967. Alberta Society of Petroleum Geologists, Calgary.

LEgRAND, P. 1981. Essai sur la paléogéographie du Silurien au Sahara Algérien. Compagnie Française des Pétroles, Notes et Mémoires 16, 9-24.

Legrand, P. 1985. Lower Palaeozoic rocks of Algeria, 5-89. In Holland, C.H. (ed.) Lower Palaeozoic of north-western and west central Africa, Lower Palaeozoic rocks of the world 3. J. Wiley \& Sons, Chichester.

LEGRAND, P. 1999. Approche stratigraphique de l'Ordovicien terminal et du Silurien inférieur du Sahara algérien par l'étude des Diplograptides (Graptolites). 892 pp. Thèse doctorat d'Etat, Université Michel de Montaigne, Bordeaux III, EGID, France.

MalETZ, J. 1997. The rhabdosome structure of a Saetograptus species (Graptoloidea, Monograptacea) from a North German glacial boulder. Paläontologische Zeitschrift 71(3/4), 247-255.

McCoy, F. 1855 in Sedgwick, A. \& McCoy, F. 1851-1855. A synopsis of the classification of the British Palaeozoic rocks, with a systematic description of the British Palaeozoic fossils in the Geological Museum of the University of Cambridge. 661 pp. London \& Cambridge.

MeyendorfF, A. 1939. La série primaire du Touat (Sahara occidental). Comptes Rendus de l'Académie des Sciences de Paris 209, 324-326.

MüNCH, A. 1938. Einige grundlegende Fragen über Bau und Struktur von Monograptus Gein. und Barrandeograptus Boucek. Zeitschrift für Geschiebeforschung und Flachlandgeologie 14(1), 1-40.
MüNCH, A. 1952. Die Graptolithen aus dem Anstehenden Gotlandium Deutschlands und der Tschechoslowakei. Geologica 7, 1-157.

Obut, A.M., Sobolevskaya, R.F. \& Bondarev, V.I. 1965. Graptolity silura Taimyra. 120 pp. Akademiya nauk S.S.S.R., Sibirskoe otdelenie, Institut geologii i geofiziki. Nauka, Moscow.

P̌̌IBYL, A. 1942. Revise pristiograptů z podrodu Colonograptus nov. subg. a Saetograptus nov. subg. Rozpravy II. třídy České akademie věd 52(15), 3-24.

PřIBYL, A. 1943. Revise zástupců rodu Pristiograptus, ze skupiny $P$. dubius a $P$. vulgaris z českého a cizího siluru. Rozpravy II. tř́dy České akademie věd 53(4), 1-48.

PřIBYL, A. 1948. Bibliografický seznam českých silurských graptolitů. Knihovna Státního geologického ústavu Československé republiky 22, 3-96.

PřIBYL, A. 1983. Graptolites biozones of the Kopanina and Př́idolí Formations in the Upper Silurian of central Bohemia. Časopis pro mineralogii a geologii 28(2), 149-167.

RicKARDS, R.B. 1976. The sequence of Silurian graptolite zones in the British Isles. Geological Journal 11(2), 153-188. DOI 10.1002/gj.3350110205

RiCKARDS, R.B. 1989. Exploitation of graptoloid cladogenesis in Silurian stratigraphy, 267-274. In Holland, C.H. \& BASSETT, M.G. (eds) A global standard for the Silurian System. National Museum of Wales, Geological series 9.325 pp. Cardiff.

Ruedemann, R. 1934. Paleozoic plankton of North America. Geological Society of America, Memoir 2, 1-141.

Ruedemann, R. 1947. Graptolites of North America. Geological Society of America, Memoir 19, 1-652.

Seilacher, A., Drozdzewski, G. \& Hunde, R. 1968. Form and function of the stem in a pseudoplanktonic crinoid (Seirocrinus). Paleontology 11, 275.

Spasov, C. 1958. Fossilite na Bulgariya. Vol. I. Paleozoi. 90 pp. Izdanie na Bulgarskata Akademiya Na Naukite, Sofia.

SPJELDNAES, N. 1967. The paleogeography of the Tethyan region during the Ordovician. 45-77. In AdAms, C.G. \& AgER, D.V. (eds) Aspects of Tethyan Biogeography. Systematic Association Publication 7.

Strachan, I. 1997. A bibliographic index of British graptolites (Graptoloidea), Part 2. Monograph of the Palaeontographical Society, 41-155.

Teller, L. 1969. The Silurian biostratigraphy of Poland based on graptolites. Acta Geologica Polonica 19(3), 393-501.

TомсZYк, H. 1956. Wenlock i Ludlow w synklinie Kieleckiej Gor Swietokrzyskich. Instytut Geologiczny Prace 16, 1-129.

Tyson, R.V. \& Pearson, T.H. 1991. Modern and ancient continental shelf anoxia: an overview, 1-24. In Tyson, R.V. \& PeARson, T.H. (eds) Modern and ancient continental shelf anoxia. Geological Society of London, Special Publications 58.

URBAneK, A. 1958. Monograptidae from erratic boulders of Poland. Paleontologia Polonica 9, 1-105.

WATERLOT, G. 1945. Les graptolites du Maroc. 1ère partie: généralités sur les graptolites. Notes et mémoires du Service des Mines et de la Carte géologique du Maroc 63, 1-112.

Wood, E.M.R. 1900. The Lower Ludlow Formation and its graptolite fauna. Quaterly Journal of the Geological Society, London 56, 415-492.

DOI 10.1144/GSL.JGS.1900.056.01-04.26

Zalasiewicz, J.A., Rushton, A.W.A., Hutt, J.E. \& Howe, M. 2000. Atlas of Graptolite Type Specimens I. 100 pp. Paleontographical Society, Berkshire. 